viện (chiếm 6,7\%). Đánh giá sau 5 ngày điều trị, $40,4 \%$ trẻ có rối loạn tri giác lúc vào giảm còn $2,4 \%$, trẻ bị co giật $4,3 \%$ giảm còn $2,4 \%$ ( 2 trẻ); thiếu máu $82 \%$ giảm còn $63,9 \% ; 3$ trẻ suy hô hấp năng lúc vào đã cai được máy, chỉ còn thở oxy hố trợ.

Kết quả cho thấy nồng độ chì máu đã giảm dần trong quá trình điều trị. Sau 5 ngày, nồng độ

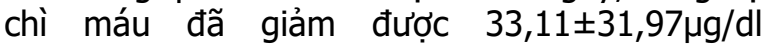
$(30,6 \%)$ và chì niệu đã tăng thải được $0,586 \pm$ $0.702(82,3 \%)$. Kểt quả này tương tự với nghiên cứu của Nguyễn Anh Tuấn trên 67 bệnh nhân được điều trị bằng EDTA với liều $25 \mathrm{mg} / \mathrm{kg} / \mathrm{ngày}$, nồng độ chì máu giảm trung bình $14,08 \mu \mathrm{g} / \mathrm{dl}$ $(27,22 \%)$, chì niệu trung bình $0,59 \pm 0,38$. Đặc biệt sau 30 ngày điều trị nồng độ chì máu đã giảm được 49,7\%, sau 1 năm giảm $71,3 \%$. Mức độ nặng của bệnh đã được giảm dần, tại thời điểm 90 ngày điều trị, chỉ còn bệnh nhân ở mức độ nhe và trung bình. Sau 1 nằm theo dõi chỉ còn 1 bệnh nhân ở mức độ trung bình với nồng độ chì máu 63,2 $\mu \mathrm{g} / \mathrm{dl}[6]$.

\section{KẾT LUÂNN}

Biểu hiện lâm sàng của ngộ độc chì cấp ở trẻ em chủ yếu là co giật và thay đổi tri giác, da xanh. Biểu hiện cận lầm sàng đặc trưng bởi biến đổi dịch não tủy theo kiểu protein tăng, tế bào bình thường, có thể thấy sóng động kinh trên điện não đồ. Nếu được chẩn đoán và điều trị sớm thì hiệu quả tương đối tốt, giảm tỷ lệ tử vong.

\section{TÀI LIÊU THAM KHẢO}

1. American Academy of Pediatric Committee on Environmental Health (2005), "Lead exposure in children: prevent, detection, and management", Pediatric; 116; 1036.

2. Bô Y Yế (2012), "Hướng dẫn chẩn đoán và điều trị ngộ độc chi".' (Ban hành kèm theo Quyết định số 1548/QQĐ-BYT ngày 10 tháng 5 năm 2012 của Bộ trưởng Bộ Y tế). chủ biên.

3. Centers for Disease Control and Prevention (CDC) (2005), "Blood lead levels-United States, 1999-2002", MMWR Morb Mortal Wkly Rep, 54:513.

4. Ngô Tiến Đông, Pham Thi Vân Anh, Pham Vắn Thắng (2012), "Ngộ độc chì ở trẻ em liên quan đến sử dụng thuốc nam: một số đặc điểm dịch tể, lâm sàng, cân lâm sàng và nhận xét kết quả điệu trị", Tạp chí y học.

5. Nguyển Anh Tuấn, Phàm Duế, Bế Hông Thu và cộng sự (2013), "Nhận xét hiệu quả bước đầu điều trị Ngộ độc chì ở trẻ em bắng EDTA tại trung tâm chống độc bênh viên Bach Mai 20122013",Kỷ yếu hội nghị chống độc quốc tế Hà Nội 2013:113- 25

6. Ngô Việt Hưng (2013), "Nghiên cứu đặc điểm lâm sàng, cận lâm sàng ngộ độc chì ở trẻ em điều trị tại Trung tâm chống độc Bạch Mai", Luận văn thạc sỹ, Đại học Y Hà Nội.

\title{
NGUYÊN NHÂN PHẢN VÊ VÀ ĐĂC ĐIỂM LÂM SÀNG THEO NGUYÊN NHÂN Ở TRẺ EM TẠI BỆNH VIỆN NHI TRUNG ƯO'NG (2017-2021)
}

\section{Đinh Thị Thu Phương*, Lê Ngọc Duy*, Trương Thị Mai Hồng*}

\section{TÓM TẮT}

Muc tiêu: Mô tả nguyên nhân phản vê và đăc điểm lầm sàng theo nhóm nguyên nhân tại Bệnh việ̉n Nhi Trung ương. Đối tượng và phướng pháp: nghiên cứu mô tả cắt ngang 129 trẻ phản vệ tại Bệnh viên Nhi Trung ương tữ tháng $1 / 2017$ đến i/2021. Kết quả: $63,6 \%$ trẻ dưới 1 tuổi; tỷ lệ nam/nữ: 1,4/1, trong đó $64,3 \%$ người bệnh được chuyển lên từ các cơ sở y tế. Thuốc là nguyên nhân gây phản vệ cao nhất: $62,8 \%$, vắc xin: $18,6 \%$, thức ăn: $14 \%$, côn trùng đốt 3,9\%... Các triệu chứng lâm sàng của phản vê đa dạng theo nhóm nguyên nhân: do thuốc biểu hiên ở tuân hoàn $(91 \%)$ và thần kinh $(88 \%)$; do vắc xin biểu hiện ở hệ tuần hoàn $(92 \%)$, thần kinh $(96 \%)$; do thức ăn và côn trùng biểu hiện nhiều ở da và niêm

*Bệnh viện Nhi Trung ương

Chịu trách nhiệm chính: Đinh Thị Thu Phương

Email: dinhphuonghmu@gmail.com

Ngày nhận bài: 19.7.2021

Ngày phản biện khoa họ: 7.9.2021

Ngày duyệt bài: 20.9.2021 mạc $(100 \% ; 100 \%)$. Căn nguyên thuốc và vắc xin thường gây phản về mức đô năng, đô 3 (64,2\%; $54,2 \%)$ và độ $4(12,3 \% ; 8,3 \%)$. Kết luận: Thuốc là nguyên nhân gây phản vệ chủ yếu. Phản vệ do thuốc và vắc xin biểu hiện triệu chứng nhiều ở hệ tuân hoàn, thần kinh và thường ở mức độ năng. Phản vê do thức ăn và côn trùng chủ yếu gây triệu chứng ở niểm mạc.

Tư khóa: phản vệ, triệu chứng, trẻ em

\section{SUMMARY}

\section{CLINICAL CHARACTERISTICS BY CAUSE OF} ANAPHYLAXIS IN CHILDREN AT VIET NAM NATIONAL CHILDREN'S HOSPITAL (2017-2021)

Objectives: Trigger of anaphylaxis and characteristic symptoms for each trigger in children at Vietnam National Children's Hospital. Method: A cross-sectional descriptive study was recorded 129 patients at Vietnam National Children's Hospital from January 2017 to July 2021. Results: $63,6 \%$ of the participants are under 12 months old. The ratio of boy-girl is $1.4 / 1 ; 64.3 \%$ of patients were transferred from medical facilities. Drugs are the most common trigger of anaphylaxis $62.8 \%$, vaccines: $18,6 \%$, food: 
$14 \%$, insect venom: $3,9 \%$, others: $0,7 \%$. The symptoms are diversity: drugs anaphylactic reactions affect the circulation (91\%) and nerve system (88\%), vaccine anaphylactic reactions affect the circulation $(92 \%)$ and nerve system (96\%); food and insect venom anaphylactic reactions affects the skin and mucous membranes $(100 \%, 100 \%)$. Drugs and vaccines occur more Grade 3 anaphylaxis (64,2\%; $54,2 \%)$ and are able to occur Grade 4 anaphylaxis $(12,3 \% ; 8,3 \%)$. Conclusions: Medication is the most common trigger of anaphylaxis. Drugs and vaccines anaphylaxis affects most on the circulation and nerve system. Food and insect venom anaphylaxis affects most on mucous membranes.

Keyword: anaphylaxis, symptoms, children

\section{I. ĐẶT VẤN ĐỀ}

Phản vệ là phản ứng dị ứng xuất hiện ngay lập tức hoặc vài giờ sau khi cơ thể tiếp xúc với dị nguyên như thức ăn, thuốc, nọc côn trùng... gây ra các bệnh cảnh lâm sàng khác nhau, có thể dẫn đến tử vong nhanh chóng nếu không được chẩn đoán và điều trị kịp thời. Trong những năm gần đây, tình trạng phản vệ ở trẻ em ngày càng tăng [1]. Tỷ lệ mắc, triệu chứng lâm sàng, yếu tố nguy cơ bị phản vệ có sự khác biệt giữa các lứa tuổi, nhóm nguyên nhân và từng vùng địa lý. Ở Việt Nam đã có một số nghiên cứu về phản vệ ở trẻ em ở các tỉnh Miền nam Viêt Nam và môt số báo cáo nhỏ tập trung nhóm phản vệ nguyên nhân do thuốc [2]. Tại Bệnh viện Nhi Trung ương có một vài số nghiên cứu về phản vệ ở trẻ em nhưng mới tập trung chủ yếu ở nhóm phản vệ mức độ nặng tại khoa Điều trị tích cực [3]; cho tới thời điểm hiện nay, chưa có nghiên cứu đánh giá một cách hệ thống về đặc điểm lâm sàng theo các nhóm căn nguyên. Vì̀ vậy, chúng tôi tiến hành nghiên cứu đề tài với mục tiêu: Mô tả nguyên nhân phản vệ ở trẻ em và đặc điểm lâm sàng theo nhóm nguyên nhân tại Bệnh viện Nhi Trung ương.

\section{II. ĐỐI TƯỢNG VÀ PHƯƠ'NG PHÁP NGHIÊN CỨU}

1. Đối tượng nghiên cứu. Bệnh nhi từ 1 tháng đến 15 tuổi được chẩn đoán phản vệ tại Bệnh viện Nhi Trung ương từ 01/ 2017 đển $07 / 2021$.

Tiêu chuẩn lựa chọn bệnh nhân: bệnh nhân được chẩn đoán theo hướng dẫn chẩn đoán phản vệ thông tư 51/2017/TT-BYT ngày 29 tháng 12 năm 2017 [4].

Triệu chứng gợi ý: Nghĩ đến phản vệ khi xuất hiện triệu chứng sau:

a) Mày đay, phù mạch nhanh

b) Khó thở, tức ngực, thở rít

c) Đau bụng hoặc nôn

d) Tụt huyêt áp hoặc ngất e) Rối loạn ý thức

Các bệnh cảnh lâm sàng:

*Bệnh cảnh lâm sàng 1: các triệu chứng xuất hiện trong vài giây đến vài giờ ở da, niêm mạc (mày đay, phù mạch, ngứa...) và có ít nhất 1 trong 2 triệu chứng sau:

a. Triệu chứng hô hấp (khó thở, thở rít, ran rít).

b. Tụt huyết áp hoặc các hậu quả của tụt huyết áp (rối loạn ý thức, đại tiểu tiện không tự chủ...).

*Bệnh cảnh lâm sàng 2: có ít nhất 2 trong 4 triệu chứng sau xuất hiện trong vòng vài giây đến vài giờ sau khi người bệnh tiếp xúc với yếu tố nghi ngờ:

a. Biểu hiện ở da, niêm mạc: mày đay, phù mạch, ngứa.

b. Các triệu chứng hô hấp (khó thở, thở rít, ran rít).

c. Tụt huyết áp hoặc hậu quả của tụt huyết áp

d. Các triệu chứng tiêu hóa(nôn, đau bụng...)

* Bệnh cảnh lâm sàng 3: Tụt huyết áp xuất hiện vài giây đến vài giờ sau khi tiếp xúc với yếu tố nghi ngờ mà người bệnh đã từng bị dị ứng: giảm ít nhất 30\% HA tâm thu (HA tối đa) hoặc tụt huyết áp tâm thu so với tuổi (huyết áp tâm thu $<70 \mathrm{mmHg}$ )

\section{Tiêu chuẩn loại trừ bệnh nhân}

+ Tất cả những trường hợp có bệnh cảnh lâm sàng như phản vệ do các nguyên nhân khác: sốc nhiểm khuẩn, sốc tim, dị vật đường thở, hen phế quản, hội chứng đỏ da do tiêm Vancomycin, cơn hoảng loạn, hạ đường huyết...

+ Bệnh nhẩn hồi cứu thiếu nhiều thông tin.

\section{Phương pháp nghiên cứu}

Thiết kế nghiên cứu mô tả cắt ngang.

Cõ̃ mẫu: Chọn mẫu thuận tiện. Sử dụng một mẫu bệnh án nghiên cứu thống nhất bao gồm khai thác bệnh án từ hỏi bệnh, thăm khám, chẩn đoán, điều trị, kết quả điêu trị và thu thập từ các bệnh án lưu trữ của Bệnh viện Nhi Trung ương.

Xử lý số liệu: Dữ liệu được xử lý, phân tích bằng phần mềm SPSS 20.0.

\section{KẾT QUẢ NGHIÊN CỨU}

3.1. Đặc điểm nhóm nghiên cứu: Có 129 bệnh nhân 1 tháng đến 15 tuổi đủ tiêu chuẩn chẩn đoán phản vệ tại Bệnh viện Nhi Trung ương.

Bảng 3.1. Đặc điểm chung của nhóm nghiên cứlu

\begin{tabular}{|c|c|c|c|c|}
\hline \multicolumn{2}{|c|}{ Chỉ số } & n & \% & P \\
\hline \multirow{3}{*}{ Tuổi } & $<1$ tuối* & 82 & 63,6 & \\
\cline { 2 - 4 } & $1-4$ tuối & 29 & 22,5 & \multirow{3}{*}{0,002} \\
\cline { 2 - 4 } & $5-9$ tuối & 11 & 8,5 & \\
\cline { 2 - 4 } & $10-15$ tuối & 7 & 5,4 & \\
\hline Giới & Nam & 76 & 58,9 & 0,052 \\
\hline
\end{tabular}




\begin{tabular}{|c|c|c|c|}
\hline & Nữ & 53 & 41,1 \\
\hline \multirow{3}{*}{$\begin{array}{l}\text { Nhập } \\
\text { viện }\end{array}$} & Tự đến & 22 & 17,1 \\
\hline & Chuyển tuyến & 83 & 64,3 \\
\hline & Tại NHP & 24 & 18,6 \\
\hline
\end{tabular}

Nhân xét: Tỷ lệ trẻ phản vê giảm dân theo tuổi, hay gặp nhất ở trẻ dưới 1 tuổi chiếm $63,3 \%$, tỷ lệ mắc dưới 1 tuổi và trên 1 tuổi khác biệt có ý nghĩa thống kê với $p<0,05$; Tỷ lệ nam/nữ là 1,4 không có sự khác biêt có ý nghĩa. Trẻ từ cơ sở y tế khác chuyển đến chiếm $64,3 \%$.

3.3. Đặc điểm lâm sàng theo nhóm nguyên nhân phản vệ

\section{Căn nguyên gây phản vệ}

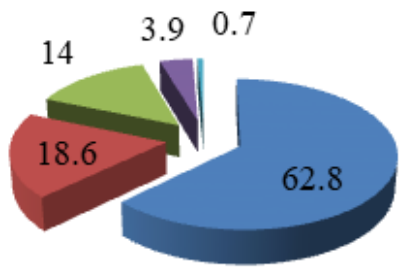

$$
\begin{aligned}
& \text { — Thuốc } \\
& \text { — Vacxin } \\
& \text { — Thức ăn } \\
& \text { — Côn trùng } \\
& \text { — Khác }
\end{aligned}
$$

\section{Biểu đồ 1: Các nhóm nguyên nhân gây} phản vê $(n=129)$

Nhânn xét: Tỷ lệ phản về do thuốc cao nhất chiếm $62,8 \%$ (trong đó thuốc kháng sinh chiếm $72 / 81$ ngoài ra còn do các thuốc khác như thuốc ha sốt, an thần, cản quang...); tỷ lệ phản vệ do vắc xin chiếm $18,6 \%$; tỷ lệ phản vệ do thức ăn chiếm $14 \%$.

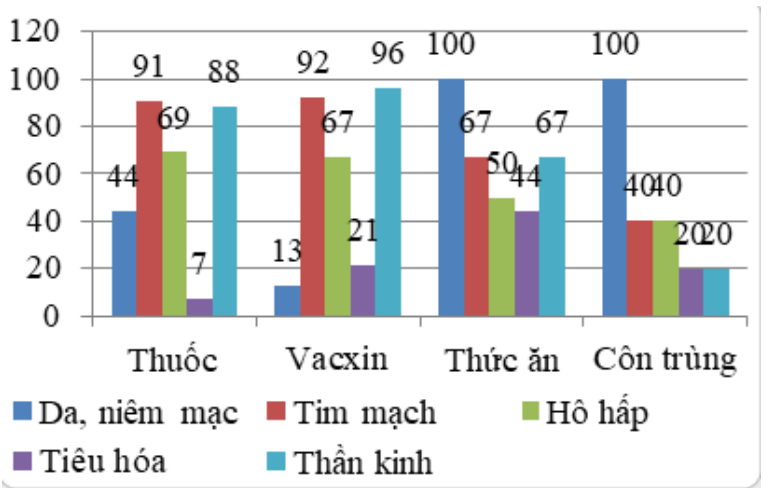

Biểu đồ 2: Triệu chứng lâm sàng các cơ quan theo nguyên nhân (\%)

Nhận xét: - Dị nguyên thuốc biểu hiện triệu chứng tim mạch $91 \%$ và thần kinh $88 \%$

- Dị nguyển vắc xin biểu hiện triệu chứng tim mach $92 \%$ và thần kinh $96 \%$

- Dị nguyên thức ăn và côn trùng biểu hiện triệu chứng da, niêm mạc 100\%
Bảng 2: Thời gian xuất hiện triệu chứng theo đường vào dị nguyên (n\%)

\begin{tabular}{|c|c|c|c|c|c|}
\hline $\begin{array}{c}\text { Dị } \\
\text { nguyên }\end{array}$ & $\begin{array}{c}\mathbf{<} \text { 5 } \\
\text { phút }\end{array}$ & $\begin{array}{c}\mathbf{5 - 3 0} \\
\text { phút }\end{array}$ & $\begin{array}{c}\mathbf{3 1 - 6 0} \\
\text { phút }\end{array}$ & $\begin{array}{c}\mathbf{6 1 -} \\
\mathbf{1 2 0} \\
\text { phút }\end{array}$ & $\begin{array}{c}\mathbf{> 1 2 0} \\
\text { phút }\end{array}$ \\
\hline Tiêu hóa & 15,4 & 30,8 & 23 & 15,4 & 15,4 \\
\hline Hô hấp & 100 & 0 & 0 & 0 & 0 \\
\hline Tiêm & 47 & 26 & 11 & 7 & 9 \\
\hline Ong đốt & 40 & 20 & 0 & 0 & 40 \\
\hline
\end{tabular}

Nhận xét: Nhóm dị nguyên đường tiêm thường xuất hiện triêu chứng sớm: dưới 5 phút chiếm 47\%; Dị nguyên đường tiêu hóa thường xuất hiện muộn hơn từ 5 đến 30 phút chiếm $30,8 \%$.

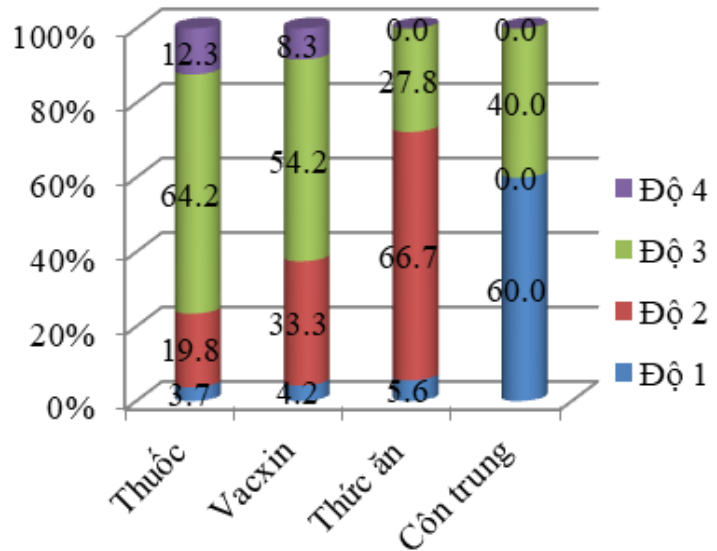

Biểu đồ 2: Phân độ nặng phản vệ theo nhóm nguyên nhân(\%)

Nhận xét: - Dị nguyên thuốc và vắc xin thường gây phản vệ độ $3(64,2 \% ; 54,2 \%)$, có gây phản vệ độ $4(12,3 \% ; 8,3 \%)$

- Dị nguyên thức ăn chủ yếu gây phản vệ độ $2(66,7 \%)$

- Dị nguyên côn trùng chủ yếu gây phản vệ độ $1(60 \%)$

\section{BÀN LUÂ̂N}

Triệu chứng lâm sàng phản vệ ở trẻ em thường đa dạng, nhiều mức độ. Nghiên cứu từ năm 2017 đến 2021, chúng tôi thu được 129 trẻ được chẩn đoán phản vệ. Trong đó nhóm bệnh nhấn nhiều nhất là dưới 1 tuổi chiếm $63,8 \%$, sau đó giảm dần theo lứa tuổi, tuổi nhỏ nhất là 1 tháng và lớn nhất là 15 tuổi. Tỷ lệ nam/nữ là $1,4 / 1$. Kết quả này tương tự nghiên cứu của Phạm Văn Thắng (2.3/1), Nguyển Xuân Quốc $(1,4 / 1)$ [2], [3]. Bệnh nhân trong nghiên cứu được chuyển từ tuyến dưới chiếm $64,8 \%$, theo sau đó là bệnh nhân phản vệ tại Bệnh viện Nhi Trung ương chiếm $18,6 \%$.

Nghiên cứu của chúng tôi ghi nhận dị nguyên 
gây phản vệ nhiều nhất là thuốc $(62,8 \%)$, trong đó chủ yếu là kháng sinh (72/81) với cả 3 đường dùng, truyền, tiêm và uống kháng sinh. Ngoài ra còn bao gồm các nhóm thuốc hạ sốt giảm đau, an thần, cản quang... Nhóm nguyên nhân sau đó là vắc xin $(18,6 \%)$, thức ăn $(14 \%)$, côn trùng đốt $(3,9 \%)$ và nguyên nhân khác $(0,7 \%)$. Kết quả này tương tự so với nghiên cứu Nguyễn Xuân Quốc (thuốc 41,9\%), Yi-Chen Hsin (thuốc 53\%) [2], [5]. Tuy nhiên so sánh với các nghiên cứu khác có nguyên nhân phản vệ nhiều nhất là thức ăn như nghiên cứu của Alberto AlvarezPerea năm 2017 (90\%), Si Hui Goh năm 2018 (55\%) [6], [7]. Sự khác biệt này có thể do có sự khác nhau về địa lý, chủng tộc, mô hình bệnh tật giữa các nước khác nhau, các nước phương Tầy tỷ lệ nhiếm trung thấp hơn nên dùng thuốc ít hơn. Mặt khác sốc phản vệ liên quan thức ăn tùy thuộc vào thói quen ăn uổng, điêu kiện địa lý và sự khác biệt về văn hóa. Vì thế cho nên có thể chế độ ăn ở Việt nam đa dạng hơn nên tỷ lệ dị ứng thức ăn thấp hơn. Thêm nữa Bệnh viện Nhi Trung ương là tuyến cuối điêuu trị bệnh lý Nhi khoa chủ yếu tập trung phản vệ mức độ nặng mà trong nghiên cứu của chúng tôi phản vệ nặng có nguyên nhân chiếm phần lớn là do thuốc.

Nghiên cứu ghi nhận thời gian biểu hiện triệu chứng sau khi tiếp xúc dị nguyên có khác nhau ở các căn nguyên, nhóm dị nguyên thông qua đường tiêm thường biểu hiện sớm trước 30 phút (73/100). Thời gian biểu hiện triệu chứng khi tiếp xúc dị nguyên qua đường tiêu hóa có thể biểu hiện sớm hoặc có thể sau vài giờ. Điều này được lý giải có thể do thức ăn có thời gian hấp thụ dị nguyên chậm hơn, giải phóng histamine chậm hơn nên biểu hiện triệu chứng muộn hơn.

Biểu hiện lâm sàng phản vệ đa dạng bao gồm $\mathrm{da}$ - niêm mạc, hô hấp, tim mạch, tiêu hóa...Khi phân tích theo từng nhóm căn nguyên chúng tôi nhận thấy nhóm căn nguyên do thuốc và vắc xin biểu hiện nhiều ở tuần hoàn và thần kinh, biểu hiện ít hơon ở da và niêm mạc. Nhóm căn nguyên do thức ăn và côn trùng đốt lại biểu hiện triệu chứng tại da và niêm mạc nhiều hơn. Khi so sánh với 1 số nghiên cứu khác cũng thấy tương đồng với nghiên cứu của Yan Xing dị nguyên thuốc biểu hiện triệu chứng nhiêu ở tim mạch (78\%) [5], nghiên cứu của Sang Yoon Kim 2017 thấy phản vệ liên quan với thức ăn biểu hiện ở da và niêm mạc nhiều hơn so với nhóm thuốc, triệu chứng tim mạch ở phản vệ do thức ăn ít hơn so với phản vệ do thuốc [8].

Mức độ phản vệ được chia thành 4 mức theo thang phẩn loại của Hướng dẫn phòng, chẩn đoán và xử trí phản vệ của Bộ Y tế 2017 dựa theo mức độ nặng của các triệu chứng lậm sàng. Nghiên cứu chúng tôi gặp chủ yếu phản vệ độ $3(56,6 \%)$ và độ $2(27,9 \%)$, có gặp phản vể độ $1(6,2 \%)$ và độ $4(9,3 \%)$. Khi nghiên cứu mức độ phản vệ giữa các nhóm căn nguyên chúng tôi nhận thấy nhóm thuốc và vắc xin phản vệ mức độ nặng cao hơn so với nhóm thức ăn và nọc côn trùng. Tuy nhiên phản vệ thường diến biến nhanh nên phản vệ mức độ nào cũng cần được chẩn đoán sớm, xử trí đúng để tránh đưa đến tử vong.

\section{KẾT LUẬN}

Nguyên nhân phản vệ ở trẻ em tại Bệnh viện Nhi Trung ương chủ yêú là do thuốc. Biểu hiện lâm sàng do thuốc và vắc xin hay hặp là thần kinh và tim mạch. Trong khi triệu chứng phản vệ do thức ăn và côn trùng biểu hiện chính là ở da và niêm mạc.

\section{TÀI LIẸU THAM KHẢO}

1. Emily Andrew, Ziad Nehme, Stephen Bernard \& Karen Smith (2018), "Pediatric anaphylaxis in the prehospital setting: incidence characteristics, and management", 0:1-7.

2. Nguyển Xuân Quốc, Phạm Văn Quạng, Tăng Chí Thượng (2015), "Đặc điểm dịch tễ, lấm sàng bệnh nhi bị sốc phản vệ tại bệnh viện nhi đồng 1", Nghiên cứu Y hoc, 2-2016: 15-22.

3. Pham Văn Thắng (2009), "Nhận xét một sỗ đặc điếm dịch tễ lâm sàng và kết quá điều trị bệnh nhân bị sốc phản vế do thuốc tại Bệnh viện Nhi Trung Ương", Đề Tải Nghiên Cứu Khoa Học Tại Khoa Điều Trị Tích Cực Bệnh Viện Nhi Trung Ương.

4. Bộ Y tế (2017), "Thông tử Hướng dẫn phòng, chẩn đoán và xử trí phản vệ - Số 52/2017/TT-BYT".

5. Yan Xing, Hua Zhang, Shusen Sun, Xiang Ma, Roy A. Pleasants, Huilin Tang, Hangci Zheng,
Suodi Zhai, Tiansheng WangYan Xing (2017), "Clinical features and treatment of pediatric patients with drug-induced anaphylaxis: a study based on pharmacovigilance data", European Journal of Pediatrics, 177: 145-154.

6. Alberto Alvarez-Perea, Beatriz Ameiro, Cristina Morales, Gabriela Zambrano, Ana Rodriguez, Miguel Guzmán, José Manuel Zubeldia and María L. Baeza (2017), "Anaphylaxis in the Pediatric Emergency Department: Analysis of 133 Cases After an Allergy Workup", American Academy of Allergy, Asthma \& Immunology, 5(5):1256-1263

7. Si Hui Goh et al (2018), "Cause and Clinical Presentation of Anaphylaxis in Singapore: From Infancy to Old Age", Int Arch Allergy Immunol, 175(1-2):91-98.

8. Sang-Yoon Kim, Min-Hye Kim, Young-Joo (2017), "Different clinical features of anaphylaxis according to cause and risk factors for severe reactions", Allergology International, 67(1):96-102 